\title{
De verwachte richtlijn duurzame corporate governance: verantwoord ondernemen moet hoog op de bestuursagenda
}

\author{
J.E.S. Hamster LLM $M A^{*}$
}

\begin{abstract}
De auteur bespreekt de verwachte conceptrichtlijn duurzame corporate governance. Daarbij wordt uitgebreid ingegaan op het beginsel van human rights due diligence, dat de kern zal vormen van de conceptrichtlijn. Deze ontwikkeling zal verstrekkende gevolgen hebben voor ondernemingen, en zij zullen dit onderwerp hoog op de agenda moeten zetten.
\end{abstract}

\section{Inleiding}

De komende jaren zal een veelvoud aan Europese wet- en regelgeving worden voorgesteld waarin concrete verplichtingen voor ondernemingen zullen worden vastgelegd op het gebied van zorg voor mens en milieu. Hoewel zij nog in de kinderschoenen staat en het Europese wetgevingsproces jaren kan duren, zijn de gevolgen van de verwachte voorstellen zodanig groot dat ondernemingen er goed aan doen zich hier nu alvast rekenschap van te geven. Meest in het oog springend van deze initiatieven is de verwachte conceptrichtlijn duurzame corporate governance die naar alle waarschijnlijkheid een buman rights due diligence-verplichting invoert en verregaande voorstellen zal bevatten voor een zorgplicht voor bestuurders. De consequenties daarvan kunnen nauwelijks worden onderschat. Het is belangrijk dat ondernemingen beseffen dat dit geen tick the box-compliance-exercities worden: zij beogen een fundamentele cultuuromslag te bewerkstelligen binnen de boardrooms van Europese ondernemingen.

Dit artikel neemt daarom alvast een voorschot op de belangrijkste ontwikkelingen in het Europese wetgevingsproces. Ik bespreek de aanloop naar de Europese regelgeving en wat daar op dit moment over bekend is (par. 2). Daarna zoom ik verder in op de vergaande en zeer waarschijnlijke human rights due diligence-verplichtingen (par. 3). Over de overige voorstellen op het gebied van corporate governance is op dit moment minder bekend. Zij zullen gezien hun verstrekkende aard in dit artikel kort worden benoemd (par. 4). Wanneer het voorstel daadwerkelijk zal zijn gepubliceerd, zal in een vervolgartikel uitgebreid aandacht worden besteed aan dit aspect van de

\footnotetext{
J.E.S. Hamster LLM MA is advocaat bij DLA Piper te Amsterdam.
}

conceptrichtlijn. Tot slot sta ik stil bij de betekenis van deze ontwikkelingen in Nederland (par. 5). Hoewel de afweging tussen belangen van stakeholders als zodanig al onderdeel uitmaakt van het Nederlands ondernemingsrecht, betoog ik dat de Europese voorstellen wel degelijk een fundamentele omslag in doen en denken met zich meebrengen voor Nederlandse ondernemingen en bestuurders. Ondernemingen die niet meebewegen, kunnen juridische procedures verwachten.

2 Samenkomst verschillende initiatieven in de richtlijn duurzame corporate governance

De Europese Commissie heeft in 2018 het Action Plan for sustainable finance aangenomen. ${ }^{1}$ Een groot deel van de daarin opgenomen actiepunten ziet op de verduurzaming van investeringen: te denken valt dan bijvoorbeeld aan het initiatief om een Europese taxonomie voor duurzame activiteiten op te stellen, of initiatieven op het gebied van non-financial disclosures. Actiepunt nr. 10 ziet op het bevorderen van duurzame corporate governance. De Europese Commissie had al eerder opgemerkt dat ondernemingsbesturen een vitale rol hebben in de ontwikkeling van verantwoordelijke ondernemingen, ${ }^{2}$ en in de zogeheten EU Green Deal was expliciet de ambitie opgenomen dat duurzaamheid onderdeel moest gaan uitmaken van het corporate-governanceraamwerk. ${ }^{3}$ In dit kader heeft de Commissie opdracht gegeven tot een onderzoek naar de oorzaken van kortetermijndenken en een onderzoek naar de mogelijkheden om een zorgplicht voor milieu en mensenrechten vorm te geven, wat geresulteerd heeft in een inmiddels hevig bekritiseerd rapport van EY. ${ }^{4}$

\footnotetext{
1. Zie https://ec.europa.eu/info/publications/sustainable-financerenewed-strategy_en.

2. Zie https://eur-lex.europa.eu/legal-content/EN/TXT/?uri=CELEX: 52011DC0681.

3. Zie https://ec.europa.eu/info/strategy/priorities-2019-2024/europeangreen-deal_en.

4. Zie https://op.europa.eu/nl/publication-detail/-/publication/ e47928a2-d20b-11ea-adf7-01aa75ed71a1/language-en.
} 
Het Europees Parlement heeft ook niet stilgezeten. Op 17 december 2020 heeft het een resolutie over duurzame corporate governance aangenomen. ${ }^{5}$ Daarmee is de positie die het Parlement in zal nemen in het overleg over een toekomstige duurzame corporate-governancerichtlijn duidelijk: het Parlement beoogt niets meer en niets minder dan 'het creëren van een cultuur binnen de bestuursorganen van ondernemingen waarin rekening wordt gehouden met en gehandeld wordt overeenkomstig duurzame corporate governance'. ${ }^{6}$ Het Parlement verzoekt de Commissie onder meer een wetgevingsvoorstel in te dienen waarin expliciet wordt opgenomen dat bestuurders verplicht zijn 'om ook de langetermijnbelangen van de onderneming, de maatschappelijke belangen in bredere zin en de belangen van werknemers en andere relevante belanghebbenden in het oog te houden'?

Waar het sustainable finance-actieplan vooral ziet op bescherming van het milieu en het aanjagen van duurzaamheid, heeft een parallelle en even ingrijpende ontwikkeling plaatsgevonden binnen het rechtsgebied van business \& buman rights. De belangrijkste pilaren van dit rechtsgebied waren lange tijd twee zogeheten soft law-regelingen, de United Nations Guiding Principles en de OESO-richtlijnen voor verantwoord ondernemen. Beide niet-bindende instrumenten staan een brede zorgvuldigheidsnorm voor om risico op mensenrechtenschendingen te identificeren en de bevindingen te implementeren met het oog op het voorkomen en verminderen van zulke schendingen. Recent zijn op dit vlak verscheidene nationale en Europese wetgevingsinitiatieven als paddenstoelen uit de grond geschoten. Het gaat dan om initiatieven die ofwel sectorspecifiek (bijvoorbeeld de EU precious metals regulation ${ }^{8}$ ) van aard zijn, ofwel gericht op specifieke schendingen (bijvoorbeeld de Nederlandse Wet zorgplicht kinderarbeid en de UK Modern Slavery $A c t^{9}$ ), ofwel slechts gericht op ernstige schendingen (bijvoorbeeld de Franse Loi de vigilance ${ }^{10}$ ) dan wel slechts publicatieverplichtingen bevatten (UK Modern Slavery Act) in plaats van daadwerkelijke beleidsverplichtingen.

\subsection{Verwacht voorstel Europese Commissie}

In het voorjaar van 2020 heeft de Europese Commissie bij monde van Eurocommissaris Didier Reynders tot veler verrassing toegezegd in 2021 met een wetsvoorstel te komen waarmee op alle ondernemingen in de EU een brede zorgplicht komt te rusten environmental due diligence en buman rights due diligence uit te voeren, gebaseerd op de brede zorgplicht in de UN Guiding Principles en OESO-richtlijnen voor verant-

5. Europees Parlement, resolutie van 17 december 2020 over duurzame corporate governance (2020/2137(INI)), zie www.europarl.europa.eu/ doceo/document/TA-9-2020-0372 NL.pdf.

6. Resolutie van 17 december 2020 over duurzame corporate governance (2020/2137(INI)), p. 7.

7. Resolutie van 17 december 2020 over duurzame corporate governance (2020/2137(INI)), p. 11.

8. Verordening (EU) 2017/821.

9. Zie www.legislation.gov.uk/ukpga/2015/30/contents.

10. Zie www.legifrance.gouv.fr/eli/loi/2017/3/27/2017-399/jo/texte. woord ondernemen. Duitsland en Portugal hebben zich als tijdelijk voorzitter van de Europese Raad in de tweede helft van 2020 respectievelijk eerste helft van 2021 expliciet gecommitteerd aan de ontwikkeling van het voorstel, en ook de businessgemeenschap ziet liever een Europees level playing field dan de lappendeken aan nationale regelgeving die nu aan het ontstaan is. ${ }^{11}$ Hetzelfde geldt voor de nationale overheden, die het risico een vijandig vestigingsklimaat te realiseren door voor de troepen uit te lopen graag zo veel mogelijk willen beperken. Ook in het Europees Parlement is brede steun voor een Europese regeling, ${ }^{12}$ evenals in de nationale parlementen, die hier in 2016 in een zeldzame 'groene kaart'-procedure al uitdrukkelijk om gevraagd hadden. ${ }^{13},{ }^{14}$ Het zal geen verbazing wekken dat onder ngo's verplichte human rights due diligence altijd al veel steun had en het voorstel met instemming werd begroet. $^{15}$

Enigszins verrassend blijkt de Europese Commissie nu deze twee bewegingen op het gebied van corporate governance en human rights due diligence samen te willen voegen in één richtlijn, de richtlijn duurzame corporate governance, die zij naar verwachting voor het einde van dit jaar zal presenteren. Hoewel nog niet met zekerheid gezegd kan worden wat de inhoud van die richtlijn gaat worden, zijn de contouren van de human rights due diligence- en environmental due diligencecomponent al vrij duidelijk geworden op basis van publieke uitingen van de verantwoordelijke Eurocommissarissen, de resultaten uit de gemandateerde onderzoeken en de vraagstelling in de publieke consultatie. Over de concrete plannen uit de sustainable finance workstream is minder bekend.

Ondertussen heeft het Europees Parlement de druk opgevoerd: in september 2020 heeft de juridische commissie van het Parlement een concept human rights due diligence-

11. Zie bijv. B. Fox, Companies will support EU law on due diligence, but need assurances on liability (interview met Virginie Mahin, the global social sustainability \& human rights lead for Mondelez International), EurActiv.com, 2019, beschikbaar via: www.euractiv.com/section/ economy-jobs/interview/companies-will-support-eu-law-on-duediligence-but-need-assurances-on-liability/.

12. Europees Parlement, resolutie van 25 oktober 2016 over ansprakelijkheid van ondernemingen voor ernstige mensenrechtenschendingen in derde landen (2015/2315(INI)), zie www.europarl.europa.eu/doceo/ document/TA-8-2016-0405_EN.html; Europees Parlement, resolutie van 29 mei 2018 over duurzame financiering, (2018/2007(INI)), zie www.europarl.europa.eu/doceo/document/TA-8-2018-0215_EN.html.

13. Zie https://corporatejustice.org/news/132-members-of-8-europeanparliaments-support-duty-of-care-legislation-for-eu-corporations.

14. In 2016 sprak de Europese Raad al onomwonden zijn steun uit voor een actieplan van de Europese Commissie om een level playing field voor business \& human rights te creëren en de UNGP's te implementeren, onder expliciete verwijzing naar het human rights due diligence-proces. Aanbeveling $\mathrm{CM} / \operatorname{Rec}(2016) 3$ van de Raad van Ministers van 2 maart 2016.

15. Zie bijv. de resolutie van de European Trade Union Confederation (ETUC), ETUC Position for a European directive on mandatory human rights due diligence and responsible business conduct, zie www.etuc.org/en/document/etuc-position-european-directivemandatory-human-rights-due-diligence-and-responsible\#: :text $=$ The $\% 20$ ETUC\%20calls\%20for\%20a,their\%20supply\%20and $\% 20$ subcontracting\%20chains. 


\section{Maandblad}

Ondernemingsrecht

richtlijn opgesteld. ${ }^{16}$ Deze conceptrichtlijn is op 8 maart 2021 in een stemming in het Europees Parlement met een ruime meerderheid aangenomen. Daarmee heeft het Parlement het initiatief tot wetgeving naar zich toe getrokken - hoewel het dat formeel gezien niet heeft - voorafgaand aan de aangekondigde wetgevingsinitiatieven van de Commissie. ${ }^{17}$ Het Europees Parlement geeft hiermee vooral een signaal af: het zal niet snel akkoord gaan met een afgezwakte variant van de eerdere toezeggingen van Eurocommissaris Reynders.

Er is natuurlijk nog een lange weg te gaan van deze aankondiging tot daadwerkelijke inwerkingtreding van een richtlijn. Oorspronkelijke wetgevingsvoorstellen kunnen bij controversiële onderwerpen in het tripartite proces flink van kleur verschieten of hun scherpe randjes kwijtraken. ${ }^{18} \mathrm{Bij}$ ingewikkelde en controversiële Europese regelgeving duurt het gemiddeld twee tot vier jaar voordat een voorstel van de Commissie uiteindelijk in het publicatieblad als richtlijn of verordening wordt gepubliceerd. ${ }^{19}$ Bij de General Data Protection Regulation (GDPR) bijvoorbeeld ging het om een periode van ruim vijf jaar. Tegelijkertijd is de grote les van de GDPR dat veel ondernemingen wensten dat ze eerder met implementatie waren begonnen. ${ }^{20}$ Bovendien lijkt er weinig twijfel te bestaan over de kernelementen van de nieuwe Europese regelgeving: naar alle waarschijnlijk wordt human rights due diligence als zorgplicht verplicht gesteld voor in ieder geval alle grote en middelgrote Europese ondernemingen. De consequenties daarvan kunnen nauwelijks worden onderschat. Datzelfde geldt voor de ingrijpende gedachtevorming over een zorgplicht voor bestuurders, het wettelijk vastleggen van een stakeholdermanagementproces en het versterken van mogelijkheden voor ngo's en andere externe stakeholders om naleving daarvan af te dwingen. Ik zet deze ontwikkelingen eerst uiteen en bespreek daarna welke consequenties dit zal hebben voor Nederlandse ondernemingen en bestuurders.

\section{Een introductie in human rights due diligence}

Human rights due diligence behelst een verplichting om het risico op mensenrechtenschendingen te identificeren, de bevindingen te implementeren met het oog op het voorkomen en verminderen van zulke schendingen, de implementatie te controleren en tot slot daarover te communiceren. ${ }^{21}$ Het leerstuk vindt zijn oorsprong in het werk van de Harvard-hoogleraar John Ruggie, die in 2005 werd benoemd tot speciaal ver-

16. Zie www.europarl.europa.eu/doceo/document/JURI-PR-657191_EN. pdf.

17. Ik ga ervan uit dat de 'gewone wetgevingsprocedure' wordt gevolgd, wat betekent dat de goedkeuring van de Raad van Ministers en het Europees Parlement vereist is (zie art. 289 en 294 VWEU).

18. Een goed voorbeeld daarvan is de richtlijn ten aanzien van collectieve acties, Richtlijn (EU) 2020/1828, die in zijn uiteindelijke vorm aanzienlijk verschilt van de eerdere voorstellen.

19. Zie www.europarl.europa.eu/infographic/legislative-procedure/index_ en.html.

20. Zie onder meer www.mckinsey.com/business-functions/risk/ourinsights/gdpr-compliance-after-may-2018-a-continuing-challenge\#.

21. Zie bijv. de definitie in de OESO Richtlijnen, hoofdstuk II, Algemene beginselen voor bedrijfsbeleid, anbeveling 145 . tegenwoordiger van de VN Secretaris-Generaal op het gebied van mensenrechten en transnationale ondernemingen. De VN Mensenrechtencommissie had op dat moment ruim veertig jaar vruchteloze pogingen gedaan regels vast te stellen voor internationaal opererende bedrijven. Ruggie presenteerde in 2008 het 'protect, respect and remedy'-raamwerk, een conceptuele benadering van de verplichtingen van overheden en ondernemingen ten aanzien van mensenrechtenschendingen die bestond uit drie pijlers:

1. de verplichting van de staat om te beschermen tegen mensenrechtenschendingen door ondernemingen;

2. de verplichting van ondernemingen om mensenrechten te respecteren; en tot slot

3. de noodzaak om slachtoffers van mensenrechtenschendingen door het bedrijfsleven betere toegang te geven tot procedures. $^{22}$

Deze principes werden door overheden, het bedrijfsleven en ngo's positief ontvangen. Vervolgens kreeg Ruggie een mandaat om met concretere aanbevelingen te komen en de reikwijdte van de verantwoordelijkheid van ondernemingen verder uit te werken. Dit resulteerde in de UN Guiding Principles on Business and Human Rights (hierna: UNGP), unaniem aangenomen door de $\mathrm{VN}$ Mensenrechtenraad in 2011. ${ }^{23}$ Deze UNGP vereisen expliciet een human rights due diligence van ondernemingen. Het doel van de VN Mensenrechtenraad en de UNGP is helder: to make human rights due diligence a part of standard business practice. ${ }^{24}$

Sinds 2011 zijn de ontwikkelingen, zeker voor VN-verband, snel gegaan. De OESO-lidstaten hebben in de gezaghebbende Guidelines for Multinational Enterprises for Responsible Business Conduct (hierna: de OESO Richtlijnen) opgenomen dat human rights due diligence een noodzakelijk onderdeel is van verantwoord zakendoen. De International Labour Organization heeft de verplichting opgenomen in de nieuwste versie van de zogenoemde Tripartite declaration of Principles concerning Multinational Enterprises and Social Policy. De EU heeft human rights due diligence verplicht gemaakt voor ondernemingen actief in de internationale mineralen- en houthandel. ${ }^{25}$ In Frankrijk geldt sinds 27 maart 2017 de Loi de vigilan$c e$, een wet die Franse moederondernemingen van een zekere omvang verplicht om een 'plan de vigilance', op te stellen, uit te voeren en te publiceren. Onderdeel van dat plan is dat ondernemingen due-diligenceonderzoek moeten doen naar de mensenrechtensituatie bij hun dochterondernemingen en in hun toeleveringsketen. In Nederland is een human rights due diligence-verplichting opgenomen in praktisch alle IMVO-

22. Verenigde Naties, The UN 'protect, respect and remedy' framework for business and human rights, 2010, p. 1.

23. Rapport van de speciaal vertegenwoordiger (A/HRC/17/31), met daaraan aangehecht de UN Guiding Principles on Business and Human Rights, aanbevolen door de VN Mensenrechtenraad per resolutie 17/4 van 16 juni 2011.

24. Rapport van de speciaal vertegenwoordiger, p. 3.

25. Verordening (EU) 995/2010 van 20 oktober 2010; Verordening (EU) 2017/821 van 17 mei 2017. 
convenanten die voor specifieke risicosectoren gesloten zijn, en zal een due-diligenceproces de kern vormen van de verplichtingen onder de Wet zorgplicht kinderarbeid, die bij algemene maatregel van bestuur ingevoerd zullen worden. Zoals hierboven vermeld, heeft Eurocommissaris Reynders aangekondigd dat human rights due diligence de kern zal vormen van het verwachte wetsvoorstel, en dat voor invulling van die verplichtingen aansluiting zal worden gezocht bij de human rights due diligence-bepalingen in de UNGP en de OESO Richtlijnen.

\subsection{United Nations Guiding Principles}

Onder de UNGP moeten ondernemingen op grond van Principe 13 vermijden dat ze mensenrechtenschendingen veroorzaken of eraan bijdragen. Ook moeten ze trachten mensenrechtenschendingen die direct gelinkt zijn aan hun operaties te voorkomen. Dat betekent, volgens Principe 15, dat ondernemingen actief beleid en procedures moeten voeren op het gebied van mensenrechten. Een van die procedures is de human rights due diligence. Ondernemingen moeten een human rights due diligence uitvoeren om mensenrechtenschendingen te identificeren, voorkomen, beperken en te vergoeden. ${ }^{26}$ Met dit doel wordt in het duediligenceproces gekeken naar zowel bestaande als mogelijke mensenrechtenschendingen, begaan door de onderneming zelf, maar ook naar schendingen die direct gelinkt kunnen worden aan hun operaties, producten of diensten, aldus Principe 17. Principe 18 tot en met 21 beschrijven vervolgens uit welke vier stappen die due diligence eruit moet zien.

De eerste stap is het maken van een impact assessment, dat wil zeggen het identificeren en analyseren van bestaande en mogelijke schendingen door de onderneming en gelieerde partijen. Daarvoor is vereist dat interne en/of onafhankelijke externe kennis en kunde op het gebied van mensenrechten wordt ingeschakeld, evenals consultatie met mogelijke slachtoffers en andere stakeholders. Vervolgens moet er in tweede instantie daadwerkelijk worden gehandeld naar de bevindingen uit de impact assessment. Het onderwerp moet adequaat worden geïntegreerd in de bedrijfsvoering, wat zoveel betekent als op het juiste niveau mensen ervoor verantwoordelijk maken. ${ }^{27}$ Ondernemingen moeten in de derde stap controleren, zowel kwalitatief als kwantitatief, in hoeverre ze inderdaad adequaat beleid ter voorkoming en beperking van de geidentificeerde schendingen hanteren. ${ }^{28}$ De vierde en laatste stap is het communiceren van de bevindingen en de daaruit volgende beleidswijzigingen. ${ }^{29}$

\subsection{OESO Richtlijnen}

De OESO Richtlijnen zijn bij de herziening van 2011 in overeenstemming gebracht met de UNGP's. ${ }^{30}$ Dat heeft in de eerste plaats geleid tot een geheel nieuw mensenrechtenhoofdstuk dat, in lijn met de UNGP's, stelt dat ondernemingen mensenrechten moeten 'respecteren'. ${ }^{31}$ Human rights due diligence wordt expliciet benoemd als uitwerking van dat uitgangspunt, en heeft ook een prominente plaats gekregen in het hoofdstuk 'Algemene Beginselen voor Bedrijfsbeleid'. Deze algemene beginselen zijn verder uitgewerkt in de 'OESO Due Diligence Handreiking voor maatschappelijk verantwoord ondernemen' uit 2018. ${ }^{32}$ Van alle documenten over human rights due diligence is dit boekwerk van meer dan honderd bladzijden het meest uitputtend. De OESO deelt human rights due diligence onder in zes verschillende stappen, ook wel de 'due diligence cycle' genoemd, die overeenkomen met de stappen uit het UNGP-proces, zij het dat ze anders - logischer - geordend zijn.

Onder de OESO Richtlijnen begint het duediligenceproces met het integreren van de OESO-beginselen van verantwoord ondernemen in beleid en bedrijfsprocessen. Onderdeel hiervan is het opstellen en publiceren van beleidsregels en het aanwijzen van een verantwoordelijke manager of afdeling. ${ }^{33} \mathrm{De}$ tweede stap is het inventariseren en identificeren van mogelijke 'negatieve gevolgen', althans van terreinen waarbinnen het risico daarop het grootst is. ${ }^{34}$ De term 'negatieve gevolgen' is een sleutelbegrip in de OESO due diligence cycle, maar wordt nergens expliciet gedefinieerd. De handreiking komt niet veel verder dan dat negatieve gevolgen verband houden met de zogenoemde MVO-thema's van de OESO Richtlijnen. ${ }^{35}$ Het is dus enigszins eigenaardig te noemen dat ondernemingen een uitgebreid beleid en processen moeten optuigen voor het identificeren en voorkomen van een situatie die verder niet of nauwelijks gedefinieerd is. ${ }^{36} \mathrm{~W}$ at daar verder ook van zij, deze inventarisatie van 'negatieve gevolgen' moet plaatsvinden door experts op dit gebied, intern of extern, en op basis van consultatie met relevante belanghebbenden, waar-

30. OESO Richtlijnen, Toelichting op hoofdstuk IV, p. 17, zie www.oesorichtlijnen.nl/documenten/brochure/201/12/8/volledigetekst-oeso-richtlijnen.

31. OESO Richtlijnen, hoofdstuk IV, aanbeveling 1.

32. Due Diligence Guidance for Responsible Business Conduct 2018, Nederlandstalige versie uitgebracht in 2019. Zie http:// mneguidelines.oecd.org/Oeso-Due-Diligence-Handreiking-voormaatschappelijk-verantwoord-ondernemen.pdf.

33. Due Diligence-Handreiking, p. 27.

34. Due Diligence-Handreiking, p. 29. Merk op dat deze 'tweede' stap in de OECD due diligence cycle de eerste stap is van de UNGP (namelijk Principe 18).

35. Mensenrechten, werkgelegenheid en arbeidsverhoudingen, milieu, omkoping en corruptie, informatie en consumentenbelangen. Zie Due Diligence-Handreiking, p. 17. Dat betekent in theorie dat bijv. ook misleidende reclame door leveranciers en afnemers onder de reikwijdte van het begrip 'negatieve gevolgen' zou kunnen vallen (want specifiek benoemd in het hoofdstuk over consumentenbescherming in de OESO Richtlijnen (p. 51)).

36. Anders dan bij de UNGP, die uitgaat van het vele malen concretere begrip 'mensenrechtenschendingen'. 


\section{Maandblad}

Ondernemingsrecht

onder begrepen potentieel geraakte groeperingen. ${ }^{37}$ Het prioriteren van verder onderzoek op basis van de ernst en waarschijnlijkheid van mogelijke negatieve gevolgen is toegestaan. ${ }^{38}$

Wanneer een risico geïdentificeerd is, moet het worden voorkomen, en wanneer negatieve gevolgen daadwerkelijk plaatsvinden, moeten deze worden stopgezet of beperkt. Een belangrijk begrip hierbij is 'leverage'. Door middel van de marktmacht die een onderneming bezit, kan en moet invloed worden uitgeoefend op zakelijke relaties die betrokken zijn bij geïdentificeerde negatieve gevolgen. ${ }^{39}$ Interessant genoeg betekent identificatie van negatieve gevolgen dus niet altijd onmiddellijk het beëindigen van een zakelijke relatie of activiteit: voortzetting kan, wanneer juist die voortzetting ertoe leidt dat leverage kan worden uitgeoefend, ervoor zorgen dat de risico's beperkt kunnen worden. ${ }^{40}$

Net als bij de UNGP's wordt veel belang gehecht aan de follow-up en monitoring van de human rights due diligence-processen. Wordt het beleid daadwerkelijk geïmplementeerd? Is het effectief? Wordt geacteerd op basis van geïdentificeerde risico's? Dit is de vierde stap van de OESO due diligence cycle. De vijfde stap vereist dat een bedrijf informatie over zijn human rights due diligence-beleid en -processen moet delen en hierover publiekelijk moet communiceren. Die communicatie moet zodanig zijn dat de effectiviteit van de door het bedrijf gehanteerde processen ook voor derden te bepalen is. Tot slot moeten effectieve herstelmaatregelen worden geboden voor zover negatieve gevolgen daadwerkelijk hebben plaatsgevonden.

\subsection{Verwachte Europese human rights due diligence}

De human rights due diligence-richtlijn van het Europees Parlement laat er weinig twijfel over bestaan: wat het Europees Parlement betreft moet er een zo breed mogelijke due-diligenceverplichting komen ten aanzien van negatieve effecten op mens en milieu. Eurocommissaris Reynders heeft aangekondigd dat ook de Europese Commissie een sterke voorkeur heeft voor een richtlijn die zal gelden voor zowel grote als kleine ondernemingen, in alle sectoren, voor alle typen mensenrechtenschendingen. Het voorstel van de Commissie zal daarmee naar alle waarschijnlijkheid daadwerkelijk een materiële verplichting behelzen voor ondernemingen om reasonable due diligence uit te voeren, schending waarvan zal leiden tot civiele aansprakelijkheid en strafrechtelijke/bestuursrechtelijke boetes.

Ik merk hier op dat Eurocommissaris Reynders, maar ook het Europees Parlement, wel heel gemakkelijk human rights due diligence en environmental due diligence met elkaar vereenzelvigen. In het Europese milieurecht is er immers al een uitge-

\footnotetext{
37. Due Diligence-Handreiking, p. 25 en 28.

38. Due Diligence-Handreiking, p. 28.

39. Due Diligence-Handreiking, p. 33.

40. Due Diligence-Handreiking, p. 34. Stopzetten van een relatie wordt als 'uiterste redmiddel' gekenschetst.
}

breid lichaam aan wet- en regelgeving rondom environmental impact assessments, terwijl de UNGP en OESO Richtlijnen toch vooral focussen op human rights due diligence. Diezelfde processen een-op-een van toepassing verklaren op de analyse van milieueffecten lijkt vragen om problemen en op het eerste gezicht wat ondoordacht.

Uit de vragen die de Commissie heeft voorgelegd in de publieke consultatie valt verder af te leiden dat de Commissie zich wel uitdrukkelijk zorgen makt over de last die een human rights due diligence- en environmental due diligence-verplichting voor kleinere ondernemingen met zich mee zullen brengen, en of er mogelijkheden zijn hen te ontlasten, bijvoorbeeld door de verplichting voor micro-ondernemingen (minder dan tien werknemers) uit te sluiten. ${ }^{41}$ Een andere vraag die expliciet voorligt, is hoe ervoor te zorgen dat een level playing field voor Europese ondernemingen ten opzichte van niet-EUondernemingen behouden kan blijven. Een van de geopperde suggesties is de verplichting uit te doen strekken tot ondernemingen die niet in de EU gevestigd zijn maar wel activiteiten in de EU verrichten. ${ }^{42}$

Tot slot ligt in de lijn der verwachting dat de Commissie erop zal willen inzetten hindernissen in de 'enforcement' van human rights due diligence- en environmental due diligence-verplichtingen zo veel mogelijk weg te nemen. Dan valt te denken aan voorstellen op het gebied van bevoegdheid en toepasselijk recht onder de EEX- en Rome II-verordeningen - zoals die ook in de conceptrichtlijn van het Parlement te vinden zijn -, die het gemakkelijker moeten maken procedures tegen dochter- én moedervennootschappen in de Europese rechtsruimte te beginnen.

\section{Overige verwachte voorstellen}

Hierboven besprak ik dat over de voorstellen in de conceptrichtlijn die voortvloeien uit de sustainable finance workstream minder bekend is. De Europese Commissie heeft EY een onderzoek uit laten voeren naar manieren om kortetermijndenken in het bedrijfsleven tegen te gaan (hierna: het EYrapport). Ondanks stevige kritiek daarop van wetenschappers blijkt uit de publieke consultatie dat de Commissie de beleidsinitiatieven voorgesteld in het rapport serieus in overweging neemt. ${ }^{43}$ Het Europees Parlement heeft zich al overtuigend achter deze beleidsinitiatieven geschaard en de Commissie opgeroepen hier werk van te maken. Dat alles is voldoende reden ook nu reeds kort stil te staan bij de drie belangrijkste aanbevelingen uit het rapport. ${ }^{44}$

41. Vraag 16 van de online consultatie.

42. Vraag 17 van de online consultatie.

43. Inception Impact Statement, 30 juli 2020, zie https://ec.europa.eu/ info/law/better-regulation/have-your-say/initiatives/12548Sustainable-corporate-governance. Het rapport zelf is te downloaden via https://op.europa.eu/nl/publication-detail/-/publication/e47928a2d20b-11ea-adf7-01aa75ed71a1/language-en.

44. Zie voor een uitgebreide analyse van het rapport en de kritiek daarop B.J. de Jong, Duurzame corporate governance: Europese en Nederlandse ontwikkelingen, Ondernemingsrecht 2021/33, p. 195. 
Het EY-rapport stelt in de eerste plaats dat kortetermijndenken of 'short-termism' voor een belangrijk deel wordt veroorzaakt door de neiging het vennootschappelijk belang en de daaraan verbonden verplichtingen van het bestuur nauw op te vatten, waarbij maximalisatie van aandeelhoudersbelangen op korte termijn de bovenhand heeft. Op basis van die conclusie stellen de onderzoekers als beleidsoptie voor een bredere, althans meer expliciete zorgplicht voor bestuurders op te nemen. ${ }^{45}$ In haar consultatie vraagt de Commissie inderdaad zienswijzen over de vraag of de zorgplicht van bestuurders explicieter in de wet moet worden vastgelegd, en op welke wijze. Varianten die in de consultatie de revue passeren, zijn onder meer het opnemen van de verplichting de belangen van alle stakeholders tegen elkaar af te wegen, waarbij de vraag wordt gesteld met welke termijn indachtig zo'n belangenafweging moet plaatsvinden - meer dan drie tot vijf jaar wordt in de consultatie als richtsnoer genoemd, meer dan vijf tot tien jaar in het EY-rapport. ${ }^{46}$ Ook wordt gesuggereerd dat het proces rondom die belangenafweging - het zogeheten stakeholdermanagement - expliciet in de wet wordt vastgelegd, zodat er niet alleen sprake is van een materiële verplichting, maar ook van een procedurele verplichting.

In de tweede plaats vond het EY-rapport dat naleving van de verplichting van het bestuur te handelen in het langetermijnbelang van de vennootschap - zo die verplichting al in de nationale rechtsstelsels wordt aangenomen - sterk gehinderd wordt door de gebrekkige mogelijkheden naleving van die verplichting af te dwingen. De Commissie onderzoekt daarom of het nodig is externe 'enforcement mechanisms' te versterken, dat wil zeggen: buiten de gebruikelijke organen van de vennootschap. Dit aspect kan dus zomaar leiden tot het faciliteren van juridische procedures door externe partijen - de consultatie benoemt expliciet civil society stakeholder groups en ngo's op milieugebied -, maar kan ook betekenen dat de Commissie de instelling van nieuwe interne organen overweegt, zoals een maatschappelijke raad. Dat zou immers nauw samenvallen met de hierboven besproken wens stakeholdermanagement robuuster vorm te geven.

Tot slot ligt in de lijn der verwachting dat de Commissie met voorstellen komt om de beloning van bestuurders in overeenstemming te brengen met de langetermijnbelangen van de onderneming in plaats van de kortetermijnbelangen van de aandeelhouder. Om dat op zinnige wijze te kunnen doen suggereert de Commissie aan te sluiten bij enkele andere initiatieven in het kader van het Sustainable Action Finance Plan ten aanzien van de niet-financiële performance van ondernemingen. Zo vraagt de Commissie input op het idee de beloning te koppelen aan verplichte duurzaamheidscores die in het kader van onder meer de taxonomy en de Non-Financial

45. Opvallend genoeg praktisch gelijktijdig met een soortgelijke oproep daartoe van Nederlandse hoogleraren ondernemingsrecht. Of sprake is van enige bewuste planning, of dat dit een mooi voorbeeld van de werking van de zeitgeist is, is mij niet bekend.

46. EY-rapport, p. viii.
Reporting Directive ontwikkeld worden. Een ander voorstel is het verplicht opnemen van $\mathrm{CO}_{2}$-reductie als een van de variabele componenten van het beloningsbeleid.

Enkele beleidsvoorstellen uit het EY-rapport zijn niet expliciet teruggekomen in de consultatie. Dat ziet onder meer op het voorstel de aandeelhoudersrichtlijn te wijzigen om langer aandeelhouderschap aantrekkelijker te maken, het voorstel om de Transparantierichtlijn zo te wijzigen dat het beursgenoteerde ondernemingen wordt verboden op kwartaalbasis winstverwachtingen af te geven, en het voorstel dat de EU regels moet stellen omtrent quota of kwaliteitseisen op het gebied van ESG (environmental, social, and governance) in de samenstelling van een ondernemingsbestuur. Een aanwijzing dat de Commissie deze voorstellen naast zich neerlegt, lijkt dat niet te zijn. Veeleer gaat het om voorstellen die betrekking hebben op andere richtlijnen of een compleet zelfstandige richtlijn, en die om die reden niet zijn opgenomen in de consultatie voor de duurzame corporategovernancerichtlijn. Ook op dit vlak is het dus zaak de Europese wetgevingsontwikkelingen nauwlettend in de gaten te houden.

\section{Gevolgen voor Nederlandse ondernemingen en bestuurders}

Er zijn de nodige kritische kanttekeningen te plaatsen bij zowel de grondslagen als de gesuggereerde uitwerkingen van de conceptrichtlijn. Ten aanzien van de human rights due diligence-regeling in de conceptrichtlijn is de voornaamste zorg dat human rights due diligence zoals we dat nu kennen een vrijwillig, non-binding instrument is. Professor Ruggie is een wereldwijd erkend expert op het gebied van internationale betrekkingen, geen jurist, en met de UNGP heeft hij geen juridisch bindend document willen schrijven. Het is, zowel in terminologie als in opzet, een document dat is opgesteld door beleidsdenkers, niet door juristen. ${ }^{47}$ Voor zover Ruggie voor ogen zou hebben gehad dat human rights due diligence de kern zou vormen van een brede juridisch afdwingbare zorgplicht voor ondernemingen, wordt daar in ieder geval met geen woord over gerept in de UNGP zelf en de begeleidende guidance. ${ }^{48}$ Bestaande juridische analyses van human rights due diligence zijn vooral van de hand van specialisten in het internationale publiekrecht en mensenrechten, niet van experts op het gebied van nationaal verbintenissen- en ondernemingsrecht. ${ }^{49}$ Het zal niet eenvoudig zijn een vertaalslag te maken van een beleidsdocument naar een werkbaar juridisch leerstuk in nationale rechtsstelsels.

47. O. Martin-Ortega, Human rights due diligence for corporations: From voluntary standards to hard law at last? Netherlands Quarterly of Human Rights 2014/32, p. 44-74, i.h.b. p. 55-56; N. Jaegers, UN Guiding Principles: Making a headway, Netherlands Quarterly of Human Rights 2011/159, p. 27.

48. Die vermelden expliciet dat juridische vragen tot het domein van het nationale recht behoren, zie commentaar bij Principe 12 .

49. Zie bijv. J. Bonnitcha \& R. McCorquodale, The concept of 'due diligence' in the UN Guiding Principles on Business and Human Rights, European Journal of International Law 2017/28, p. 899; Martin-Ortega 2014 


\section{Maandblad \\ Ondernemingsrecht}

\subsection{Corporate governance}

Ten aanzien van de corporate-governanceaspecten van de richtlijn valt vooral te wijzen op de gebrekkige onderbouwing van het EY-rapport. Het lijkt voorbarig zodanig vergaande ingrepen te doen in het nationale ondernemingsrecht op basis van een analyse waar wetenschappers fundamentele kritiek op hebben. ${ }^{50}$ Bovendien zullen het nut en de noodzaak van de verwachte wijzigingen per jurisdictie verschillen: voor het juist inpassen van een nieuw leerstuk is stevige academische discussie vereist, zoals die nu in Nederland plaatsvindt ten aanzien van het hooglerarenvoorstel voor de maatschappelijke zorgplicht.

Het valt dus te hopen dat de Europese Commissie zeer zorgvuldig te werk zal gaan bij het opstellen van de conceptrichtlijn. Ik wil in dit artikel niet te lang stilstaan bij kritiek op de mogelijke aspecten van de conceptrichtlijn - dat lijkt meer opportuun wanneer de conceptrichtlijn daadwerkelijk gepubliceerd zal zijn. Het lijkt voor nu zinniger ondernemingen en hun juridisch adviseurs te wijzen op de verstrekkende gevolgen van deze ontwikkelingen.

Die verstrekkende gevolgen zien voor Nederland niet zozeer op de maatschappelijke zorgplicht voor bestuurders. Dat ligt voor andere lidstaten misschien anders, maar in Nederland geldt tenslotte al als uitgangspunt dat het bestuur zich richt op waardecreatie op de lange termijn en daarbij de belangen van alle bij de onderneming betrokken belanghebbenden afweegt. ${ }^{51}$ Het is dus zelfs nog maar de vraag of dit aspect van de richtlijn tot wijziging van Boek 2 BW zou moeten leiden. ${ }^{52}$ Wel kan worden betoogd - zoals in de bekende oproep van 25 hoogleraren - dat wettelijke verankering van die zorgplicht meer duidelijkheid en richting geeft, nu de belangenafweging zich in de praktijk nog sterk richt op de belangen van aandeelhouders. ${ }^{53}$

Het zal in de eerste plaats vooral het duediligenceproces zijn dat een fundamentele omslag in de corporate governance van Nederlandse ondernemingen zal veroorzaken. Als dit proces inderdaad wordt opgezet in overeenstemming met de UNGP's of de OESO Richtlijnen, dan kan zorg voor het juist uitvoeren van dit proces niet bij een complianceafdeling

50. Ik benoemde al dat er vanuit de wetenschap fundamentele en goed onderbouwde kritiek is geleverd op het EY-rapport; zie de kritiek van de European Company Law Experts (ECLE)-groep, https:// europeancompanylawexperts.wordpress.com/publications/europeancommission-study-on-directors-duties-and-sustainable-corporategovernance/, en de kritiek van Harvard-hoogleraren Roe e.a., The EY sustainable corporate governance report's major flaws: Discussion and analysis, 2020, zie https://ecgi.global/news/european-commission $\% \mathrm{E} 2 \% 80 \% 99$ s-sustainable-corporate-governance-report-critique.

51. HR 4 april 2014, ECLI:NL:HR:2014:799, NJ 2014/286 (Cancun), en Principe 1.1 van de Corporate Governance Code.

52. Zie De Jong 2021, p. 201. Zie ook S.B. Garcia Nelen, Een Europees initiatief voor duurzame corporate governance, Ondernemingsrecht 2021/32, p. 191.

53. J.W. Winter e.a., Naar een maatschappelijke zorgplicht voor bestuurders en commissarissen - antwoord op de reacties, Ondernemingsrecht 2021/6, p. 31-39. worden ondergebracht: staffuncties als legal, finance, communications, compliance, inkoop en human resources zullen in dit proces een rol te vervullen hebben, en uiteindelijk is het aan het bestuur om het proces te coördineren en daadwerkelijk een afweging te maken tussen de belangen die geïdentificeerd zijn in de due-diligence-exercitie. Concreet betekent dit voor het bestuur dat de resultaten van het duediligenceonderzoek en de belangenafweging daadwerkelijk agendapunten worden voor de bestuursvergadering. Daarbij is adequaat toezicht op deze processen essentieel: ook een eventuele raad van commissarissen en audit committee hebben dus een belangrijke taak te vervullen.

\subsection{Toename procedures en verdere institutionalisering stakeholdermodel}

In de tweede plaats zullen juridische procedures tegen ondernemingen en bestuurders zonder twijfel toenemen. Strategisch procederen op het terrein van mensenrechten en duurzaamheid is sowieso al een onmiskenbare trend de afgelopen jaren. ${ }^{54}$ Ngo's hebben ontdekt dat procederen een effectieve strategie is om hun doelen te verwezenlijken. ${ }^{55}$ Daar staat tegenover dat voor de zogeheten parent company liability veel juridische hordes genomen moeten worden: wist de moedermaatschappij van de onrechtmatigheden, bemoeide zij zich intensief met het beleid van de dochteronderneming, vallen slachtoffers aan te merken als een partij waartegenover de moedermaatschappij een zorgplicht had? ${ }^{56}$ De invoering van een duediligenceverplichting betekent dat eisers over al die hordes heen kunnen springen. Laat het bestuur steken vallen in het duediligenceproces, dan is handelen in strijd met de wet een gegeven, en daarmee onrechtmatigheid. De vraag of de Nederlandse moeder zich intensief bemoeide met het lokale beleid doet simpelweg niet meer ter zake, evenals de vraag of de moedermaatschappij wetenschap had. $\mathrm{Zij}$ zal op grond van de due-diligenceregels kennis moeten hebben over de mogelijke mensenrechtelijke consequenties van lokaal beleid, en heeft zij dat niet, dan is ook daarmee de onrechtmatigheid gegeven.

Daarmee ligt in de lijn der verwachting dat het aantal juridische procedures door ngo's en belangenorganisaties tegen ondernemingen op het gebied van duurzaamheid en mensenrechten toe zal nemen. Die beweging wordt nog versterkt door de plannen van de Commissie om private handhavingsmechanismes op te tuigen. Private enforcement is hard op weg het favoriete handhavingsinstrument van de Europese

54. Zie bijv. de driemaandelijkse overzichten van het Business \& Human Rights Resources Center met alle strategische procedures om ondernemingen aansprakelijk te houden voor mensenrechtenschendingen of milieuproblemen.

55. Zie hierover M.E. Coenraads \& J.E.S. Hamster, Verantwoord ondernemen: van soft law naar harde verplichtingen via strategisch procederen, TOP 2019/8.

56. Al deze elementen komen bijv. terug in de Shell Nigeria-arresten van Hof Den Haag 29 januari 2021, ECLI:NL:GHDHA:2021:134; zie hierover uitgebreid het proefschrift van L.F.H. Enneking, Foreign direct liability and beyond (diss. Rotterdam), Den Haag: Eleven International Publishing 2012. 


\section{Maandblad \\ Ondernemingsrecht}

Commissie te worden: de bereidheid van actiegroepen om als wakkhonden op te treden is de Europese Commissie op veel terreinen als een zeer belangrijk handhavingsinstrument gaan zien. Zowel in het mededingingsrecht als in het privacyrecht en consumentenrecht is de Commissie uitgesproken voorstander van civielrechtelijke procedures om ondernemingen bij de les te houden. ${ }^{57}$ De betekenis daarvan kan niet worden onderschat: waar private enforcement van het mededingingsrecht vijftien jaar geleden in de Europese Unie nog een zeldzaamheid was, heeft menig groot advocatenkantoor thans advocaten in dienst die zich hier zo goed als voltijd mee bezighouden. Dat ESG litigation waarin human rights due diligence een onderwerp van geschil is nu nog slechts sporadisch voorkomt, heeft dus weinig voorspellende waarde. ${ }^{58}$ Dit alles betekent dat een onderneming die er te laat of onvoldoende in slaagt het human rights due diligence-proces daadwerkelijk te integreren in haar risicomanagement en haar bestuurlijke belangenafweging, een groot risico loopt op procedures door private wakkhonden als ClientEarth en SOMO.

Hiermee hangt samen een derde onmiskenbare trend, namelijk een verdere institutionalisering van het stakeholdermodel. Het consultatiedocument lijkt niet alleen te suggereren dat de private handhaving in de vorm van 'externe' aansprakelijkheidsprocedures gegoten zal worden, maar ook dat de positie van 'stakeholders' stevig wettelijk verankerd wordt. Enerzijds zou dat effect kunnen hebben op de governance van een onderneming - de consultatie werpt de mogelijkheid van een stakeholdervergadering op -, anderzijds betekent het dat een grotere groep belanghebbenden of stakeholders een rol zal gaan spelen in procedures die welbeschouwd tot op heden als 'intern' werden beschouwd. Daarbij valt bijvoorbeeld te denken aan de procedure tot vernietiging van een besluit of zelfs de enqueteprocedure. De besluitvorming van het bestuur kan dan op twee wijzen worden aangevallen. Enerzijds kan worden aangevoerd dat bij de belangenafweging een onzorgvuldige procedure is gevoerd (due process), en anderzijds dat de uitkomst van de belangenafweging onredelijk benadelend is voor een bepaalde stakeholder of groep stakeholders (due content).

57. Zie in het algemeen het document van het EC Directorate General for Internal Policies, Tools for ensuring the implementation and application of EU law and evaluation of their effectiveness (2013), 17, www.europarl.europa.eu/RegData/etudes/etudes/join/2013/493014/ IPOL-JURI_ET(2013)493014_EN.pdf; zie voor het mededingingsrecht in het bijzonder onder meer voormalig Eurocommissaris voor de mededinging Mario Monti, Effective private enforcement of EC antitrust law, 1 juni 2001, https://ec.europa.eu/commission/presscorner/ api/files/document/print/en/speech_01_258/ SPEECH_01_258_EN.pdf.

58. In Frankrijk, waar human rights due diligence onderdeel uitmaakt van de Loi de vigilance, vinden nu inderdaad de eerste rechtszaken plaats, waarin het al dan niet adequaat uitvoeren van human rights due diligence een belangrijk aspect van de procedure vormt. Zie onder meer de rechtszaak tegen Total, zie www.business-humanrights.org/en/latestnews/total-lawsuit-re-failure-to-respect-french-duty-of-vigilance-law-inoperations-in-uganda/.
Bij dat alles valt op dat de Europese Commissie noch het Europees Parlement een aanzet doet dat kernbegrip 'stakeholder' verder te definiëren. Het consultatiedocument lijkt dat proces aan elke onderneming afzonderlijk over te willen laten, maar die benadering komt nog niet volledig uitgedacht voor: daarmee zou een onderneming immers zelf volledig de regie hebben over welke belanghebbenden in de belangenafweging moeten worden meegenomen, daar waar de Europese initiatieven er nu juist op gericht lijken te zijn dat een bredere kring belanghebbenden een rol krijgt in het ondernemingsbeleid.

\section{Conclusie}

Naar alle waarschijnlijkheid komt er Europese regelgeving die human rights due diligence als zorgplicht verplicht stelt voor Europese ondernemingen. De consequenties daarvan kunnen nauwelijks worden onderschat. Datzelfde geldt voor de ingrijpende gedachtevorming over een zorgplicht voor bestuurders, het wettelijk vastleggen van een stakeholdermanagementproces en het versterken van mogelijkheden voor ngo's en andere externe stakeholders om naleving daarvan af te dwingen. De noodzaak om met tijdige implementatie te beginnen geldt in het bijzonder voor human rights due diligence-aspecten van de verwachte richtlijn. Correcte naleving van deze verplichtingen vereist van een onderneming een fundamentele cultuuromslag, gestroomlijnde bedrijfsprocessen en een adequaat inzicht in alle mogelijke risico's. Daarmee hoeft een onderneming niet te wachten tot de verwachte richtlijn definitief is vastgelegd: over de materiële kernverplichtingen is immers al veel bekend. Ondernemingen en hun juridisch adviseurs doen er goed aan de ontwikkelingen nauwgezet te volgen, zich voor te bereiden op de mogelijke gevolgen en waar mogelijk een bijdrage te leveren aan het wetgevingsdebat dat zich de komende maanden en jaren zal ontspinnen. 